\title{
Effects of decompressive craniectomy, hypertonic saline solution and mannitol on an experimental model of cerebral ischemia
}

\author{
Çağatay Çalıkoğlu, M.D., ${ }^{1}$ Mehmet Hüseyin Akgül, M.D., ${ }^{2}$ Osman Akgül, M.D., ${ }^{3}$ Ayşe Karataş, M.D. ${ }^{4}$
}

${ }^{1}$ Department of Neurosurgery, Atatürk University Faculty of Medicine, Erzurum

${ }^{2}$ Department of Neurosurgery, Seydişehir State Hospital, Konya

${ }^{3}$ Department of Neuorosurgery, Düzce State Hospital, Düzce

${ }^{4}$ Department of Neuorosurgery, Katip Çelebi University Faculty of Medicine, İzmir

\begin{abstract}
BACKGROUND: Cerebral ischemia is a cause of serious morbidity and mortality. Strategies that would protect cerebral tissue against ischemic injury are important. The present study aimed to evaluate effects of surgical and medical treatments, either alone or in combination, on infarction area in an experimental rat model of cerebral ischemia.
\end{abstract}

METHODS: Adult male Sprague-Dawley rats $(n=30)$ were divided into 6 groups, each including 5 experimental animals. Cerebral ischemia was created by right common carotid artery occlusion (CCAO) under anesthesia. Decompressive craniectomy (DC) was performed in the relevant groups at the $12^{\text {th }}$ hour following CCAO, whereas medical treatments were performed in the relevant groups at the $\mathrm{I}^{\text {st }}, 12^{\text {th }}$, and $24^{\text {th }}$ hours following CCAO. After CCAO, the control group received I mL/kg physiological saline, hypertonic saline (HS) group received $3 \%$ hypertonic saline $(\mathrm{I} \mathrm{mL} / \mathrm{kg})$, and mannitol (MAN) group received $20 \%$ mannitol (I g/ $/ \mathrm{kg})$. While only DC was performed following CCAO in the DC group, DC+HS group underwent DC together with hypertonic saline treatment and DC+MAN group underwent DC together with mannitol treatment. The rats were decapitated at the end of the $24^{\text {th }}$ hour following ischemia. Cerebral sections were stained with $2 \%$ 2,3,5-triphenyltetrazolium chloride (TTC). The ratio of infarction area to the total area of section was calculated as percentage.

RESULTS: Mean infarction areas were $27.9 \%$ in the control group, $13.7 \%$ in the HS group, $15.1 \%$ in the MAN group, $10.6 \%$ in the DC group, $8.1 \%$ in the DC+HS group, and $9.7 \%$ in the DC+MAN group. Mean infarction areas were significantly lower in all groups than in the control group. While the mean infarction area did not differ between the HS and MAN groups, it was lower in the groups undergoing DC as compared to these two groups. The best outcome was observed in the DC+HS group.

CONCLUSION: Both medical and surgical treatments were effective in decreasing cerebral ischemic infarction. There was no difference between medical treatments groups in terms of efficacy, whereas DC led to a substantial decrease in ischemic infarction volume as compared with the medical treatment groups. Combined treatment approaches performed to decrease infarction volume also resulted in favorable outcomes.

Key words: Cerebral ischemia; experimental study; decompressive craniectomy; hypertonic saline; mannitol; rat.

Address for correspondence: Çağatay Çalıkoğlu, M.D.

Atatürk Üniversitesi Tıp Fakültesi, Beyin Cerrahi Kliniği,

25040 Erzurum, Turkey

Tel: +90 442 - 23। I I II E-mail: dr.cagatay33@gmail.com

Qucik Response Code Ulus Travma Acil Cerrahi Derg

20I5;2I(6):425-43।
doi: $10.5505 /$ tjtes.2015.45077

Copyright 2015

TJTES

\section{INTRODUCTION}

Stroke, the leading cause of disability, is the most devastating disease among all neurological conditions. Globally, stroke causes approximately 5.5 million deaths yearly and accounts for 44 million disability-adjusted life year lost. ${ }^{[1]}$ In addition to the economic burden of treatment during disease, economic burden due to post-treatment rehabilitation and loss of workforce also reaches to a substantial extent. ${ }^{[2]}$ Well determination of the risk factors of stroke and prevention from stroke would reduce morbidity and mortality. 
The World Health Organization defines stroke as "rapidly developing clinical signs of focal (or global) disturbance of cerebral function, with symptoms lasting for 24 hours or longer or leading to death, with no apparent cause other than of vascular origin". Eighty percent of strokes is of ischemic origin, whereas $20 \%$ is of hemorrhagic origin. ${ }^{[3]}$ The term cerebral ischemia defines inadequate blood circulation for the maintenance of normal metabolic functions of brain and results from decreased or ceased blood flow or extravasation of blood due to laceration of arteries because of various pathologies in arteries that supply brain. ${ }^{[4]}$ Energy sources (oxygen and glucose) of the neurons are depleted owing to decreased or ceased cerebral blood flow. Cerebral ischemia may be encountered as either global ischemia resulting from cardiac arrest or as focal cerebral ischemia resulting from obstruction of a single cerebral artery, and may either be temporary or permanent. ${ }^{[5]}$

The main goal in the treatment of ischemic stroke is the correction of the cause of ischemic area in an early phase. The brain area, in which blood flow decreases but permanent injury has not occurred yet, is the basic target of therapeutic approaches. If ischemic condition does not improve, these areas have the potential to develop necrosis and irreversible neuronal injury in time. ${ }^{[6]}$ The treatment of stroke is usually medical including thrombolytic therapy performed to prevent secondary injury and drugs that prevent oxidative stress and brain edema caused by stroke. Mannitol and furosemide are among osmotherapeutic agents that are most frequently used in clinical practice. However, hypertonic saline (HS) treatment has also been used in numerous experimental and clinical trials in recent years. ${ }^{[7]}$ In addition, decompressive craniectomy (DC) is a surgical treatment method used for years in experimental and clinical trials as an alternative to effective medical treatment. ${ }^{[8]}$ The goal of DC is to decrease elevated intracranial pressure and minimize the edema resulting from secondary injury that occurs in infarction area after stroke.

The present study aimed to expose the effects of medical and surgical treatments, either alone or in combination, on infarction area in an experimental model of cerebral ischemia. For this purpose, medical and surgical treatments were performed alone or in combination on rats, on which cerebral ischemia was induced by right common carotid artery occlusion (CCAO), and the results were compared.

\section{MATERIALS AND METHODS}

\section{Experimental Animals}

The present study included 30 adult male Sprague-Dawley rats, weighing between $250 \mathrm{~g}$ and $350 \mathrm{~g}$. Before the study, the rats were given ad libitum access to water and food. Approval of Düzce University, Animal Research Local Ethics Committee was obtained for the study (dated 15.02.201I and numbered B.30.2.ABU.0.05.05-050.01.04-I2). The rats were divided into six groups, each including five rats. The control group included rats on which CCAO was performed and physiological saline ( $\mathrm{I} \mathrm{mL} / \mathrm{kg}$ ) was administered. The hypertonic saline (HS) group included rats on which CCAO was performed and hypertonic saline was administered. The mannitol (MAN) group included rats on which CCAO was performed and mannitol was administered. The DC group included rats on which CCAO and DC were performed. The DC+HS group included rats on which CCAO and DC were performed and hypertonic saline was administered. The DC+MAN group included rats on which CCAO and DC were performed and mannitol was administered.

\section{Common Carotid Artery Occlusion (CCAO)}

In order to create a diffuse hemispheric ischemia, the CCAO model described by Rice et al. ${ }^{\left[{ }^{[9}\right.}$ was preferred as an experimental model of ischemic stroke. Anesthesia was performed using 75 mg/kg ketamine hydrochloride (Ketalar, Parke-Davis, UK) via intraperitoneal route. The rats were immobilized in supine position using adhesive bandage. After cleaning the surgical area using polivinilpirolidon iodine (polividon iodine $10 \%$ ), a paramedian $2 \mathrm{~cm}$ skin incision was made using No. 18 scalpel in the way that the right sternocleidomastoid muscle would be on the lateral aspect. Thereafter, CCA was exposed via microdissection. Under a surgical microscope, 8/0 Ethilon nylon filament (Ethicon, Inc., Johnson \& Johnson, New Jersey, USA) was attached to the proximal and distal aspects of the CCA and tied. The CCA was cauterized and cut between the tied points. It was sutured with $2 / 0$ silk (Ethicon, Inc.) in accordance with the dermal-subdermal anatomy.

\section{Medical and Surgical Treatment}

Medical treatments were performed in relevant groups on the $1^{\text {st }}, 12^{\text {th }}$ and $24^{\text {th }}$ hours following CCAO. Surgical treatment (DC) was performed in relevant groups at the $12^{\text {th }}$ hour following CCAO. Following CCAO, I mL/kg physiological saline was administered in the control group, 3\% hypertonic saline $(\mathrm{l} \mathrm{mL} / \mathrm{kg})$ was administered in the HS group, and $20 \%$ mannitol ( $\mathrm{l} \mathrm{g} / \mathrm{kg}$ ) was administered in the MAN group via intraperitoneal route. The DC group underwent only DC following CCAO, whereas the DC+HS group underwent DC together with hypertonic saline treatment and the DC+MAN group underwent DC together with mannitol treatment.

For DC, the rats were fixed in prone position and subdermal temporal muscle was exposed following large skin incision in the right temporoparietal region. The temporal muscle was peeled off from the bone together with periosteal layer. During DC, which was performed using a dental drill, irrigation was performed with $0.9 \%$ physiological saline for the underlying cortex not to be harmed. Following a craniectomy of $5 \times 5 \mathrm{~mm}$, the dura mater was opened by a curvilinear incision using a 30-gauge needle and the parenchymal tissue was exposed. Thereafter, the temporal muscle and the skin were properly closed. In all groups, it was observed that the right 
eyelids of the rats were closed as compared to their left eyelids after CCAO.

\section{Neurological Examination}

The scoring system, defined by Bederson et al. ${ }^{[10]}$ and modified by Kawamura et al., ${ }^{[1]}$ was used for neurological examination. Accordingly, the scoring was as follows: 0 , normal neurological examination; I, weakness in the left forepaw; 2 , circling by twisting towards to the left side while walking; 3 , falling to the left side when pushed slightly; 4 , inability to walk spontaneously.

Healthy rats normally extend their both forepaws down toward the floor when they are hung by the tail. However, the rats undergoing CCAO could not extend their contralateral front and hind extremities down toward the floor. Decreased resistance in the contralateral front extremity was assessed by observing the rats while they were gripping the bars of the cage after being hung by the tail. Resistance loss was noted in the paretic extremity in all six groups. However, no remarkable deficit was observed in any of the four extremities of the rats at the $24^{\text {th }}$ hour before they were sacrificed. The animals were sacrificed after 24 hours following CCA infarction. No significant difference was found between the groups in terms of neurological examination before decapitation.

\section{Decapitation and Staining}

The rats were decapitated 24 hours after CCAO; their brains were removed rapidly and sectioned into 7 coronal sections. A 2,3,5-triphenyltetrazolium chloride (TTC) solution was prepared at a concentration of $2 \%$ before staining. After immersing each section with $2 \%$ TTC in $0.9 \%$ physiological saline, they were incubated at $37^{\circ} \mathrm{C}$ in a dark medium for 30 minutes. After incubation, the tissues were kept in 10\% formaldehyde for the stain to penetrate into the tissues. As the consequence of these procedures, cerebral infarction areas were observed as unstained white areas, whereas intact cerebral areas were stained pink or red. Moreover, one rat without CCAO was exposed to the same procedures to obtain a normal tissue sample; it was decapitated with no medical or surgical treatment.

After the sections were kept in formaldehyde for 10 minutes following staining, they were photographed by a digital camera (Kodak 8.2 MP digital camera, USA). Since body weights and total brain areas of the rats were different, relative infarction area was calculated. For this purpose, an image analysis system (Digimizer Medical Imaging Software Version 3.7.0.0; MedCalc Software, Ostend, Belgium) was used. After calculating total brain area and infarction area, if any, in each of the 7 sections obtained from the brain of each rat, the ratio of the infarction area to the total brain area was calculated as percentage (\%).

The ratios of infarction areas (\%) were summed separately
Table I. Mean cerebral infarction area of the rats in the study groups

\begin{tabular}{lc}
\hline Groups & Cerebral infarction area (\%) \\
\cline { 2 - 2 } & Mean \pm SD \\
\hline Control & $27.9 \pm 1.9$ \\
HS & $13.7 \pm 1.5$ \\
MAN & $15.1 \pm 1.6$ \\
DC & $10.6 \pm 0.6$ \\
DC+HS & $8.1 \pm 1.0$ \\
DC+MAN & $9.7 \pm 0.4$ \\
\hline
\end{tabular}

SD: Standard deviation; HS: Hypertonic saline; MAN: Mannitol; DC: Decompressive craniectomy.

for each brain and divided by the number of sections obtained from that brain. Thereby, the percentage of the infarction area was determined for each brain. The percentages of infarction areas for each brain in each group were summed and divided by the number of rats examined; the mean infarction area was then determined for each group.

\section{Statistical Analysis}

The Predictive Analysis Software (PASW) Statistics 18.0 (SPSS Inc., Chicago, IL, USA) for Windows was used for statistical analysis. Multiple independent group comparisons were performed using the Kruskal-Wallis test, whereas subgroup analyses were performed using the Mann Whitney $U$-test with Bonferroni correction. A p value of $<0.05$ was considered statistically significant.

\section{RESULTS}

None of the rats died during perioperative period. There was no rat without infarction despite CCAO. Mean cerebral infarction rates of the rats in the study groups are demonstrated in Table I.

A significant difference was determined between the groups in terms of cerebral infarction rate $(p<0.001)$. Paired comparisons were performed in subgroup analyses. Although the level of statistical significance was $\mathrm{p}<0.00 \mathrm{I}$ according to the Bonferroni correction, $p=0.009$ was considered clinically significant because of limited number of experimental animals in the sample. Accordingly, paired comparisons revealed that the infarction rate of each experimental group was significantly lower than that in the control group ( $p<0.009$ for each). There was no significant difference between the infarction rates of $H S$ and MAN groups $(p=0.175)$. The infarction rates of $\mathrm{HS}$ and MAN groups were significantly higher than those of the DC, DC+HS, and DC+MAN groups ( $<<0.009$ for each). The infarction rate of DC+HS group was significantly lower than those of DC and DC+MAN groups ( $p<0.009$ for each). 


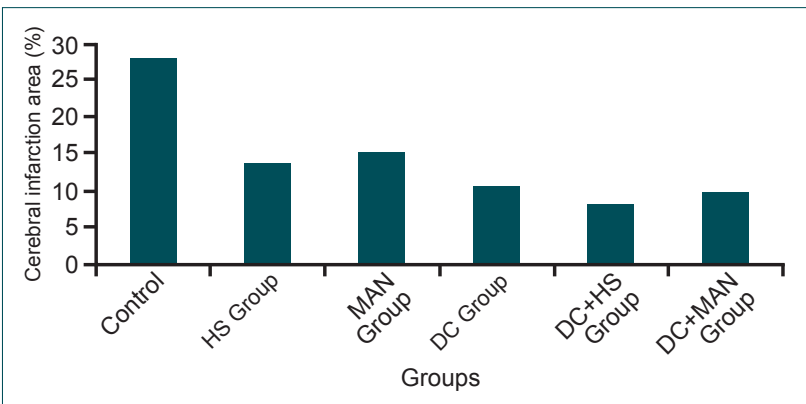

Figure 1. Cerebral infarction area in the study groups. HS: Hypertonic saline; MAN: Mannitol.

Moreover, there was no significant difference between the $D C$ and DC+MAN groups ( $p=0.047 ;$ Fig. I).

\section{DISCUSSION}

Several medical or surgical methods that have different mechanism of action were tried in the past to prevent ischemic injury and are still being tried today. Currently, there is no method or drug that would completely solve this problem. Many of the attempted drugs are effective over one or more mechanisms, cannot radically solve this chain of events, which are quite complex and multifactorial, and provide limited benefit. Under the light of current knowledge, agents that are anti-excitotoxic, anti-inflammatory, antioxidant and/or anti-apoptotic could easily pass into the central nervous system, have tolerable side effects, could be effective when used even 4-6 hours after development of ischemia, and have no unfavorable interaction with other neuron protective agents are the ideal neuron protectors. No ideal agent or method meeting these conditions has been discovered yet. Nevertheless, various neuron protective effects have been reported in the studies performed with glutamate receptor antagonists, ${ }^{[12,13]}$ calcium channel blockers, ${ }^{[14]}$ free oxygen radical scavengers, ${ }^{[15-17]}$ citicoline, ${ }^{[18]}$ hypothermia, ${ }^{[19]}$ and sometimes combination of these.

In their review, Kollmar and Schwab ${ }^{[20]}$ have expressed that experimental trials should continue and that combination therapies might be convenient in the treatment of stroke. In the present study, we also evaluated the effects of mannitol, hypertonic saline, and DC alone or in combination, neuron protective effects of which have been individually demonstrated in experimental trials, on infarction volume in ischemic injury that was created irreversibly without reperfusion following CCAO.

Many studies have demonstrated that surgical and medical treatments should be performed at early phase to reduce ischemic infarction and edema because the first 72 hours in cellular ischemic injury following occlusion is of great importance and that irreversible ischemic process following delayed treatment could not be stopped. Thus, in the present study, volume-reducing efficacy in early treatment was tried to be determined. In previous studies, either the outcomes of very early period (first 6 hours) or at the $36^{\text {th }}$ and $72^{\text {nd }}$ hours have been discussed and sacrificing performed. ${ }^{[21-24]}$

Bederson et al. ${ }^{[10]}$ have stated that TTC is a rapid, reliable, cheap, easily detectable, and convenient substance in demonstrating infarction area in the screening and recognition of cerebral infarction in rats. In the present study, we used TTC, as well.

In a clinical study by Delashaw et al., ${ }^{[25]}$ DC was performed in nine patients and neurological improvement was reported in six patients on postoperative firstday. They reported that 6 of these patients were functionally dependent and the remaining three patients were functioning with minimal assistance during a follow-up period ranging from 5 to 25 months and that hemispheric craniectomy had life-saving and life-prolonging effect in the treatment of extensive cerebral infarction and malignant cerebral edema. Rengachary et al. ${ }^{[26]}$ have reported that waiting is necessary for whole benefits of medical treatment and that DC, therefore, should not be performed before the development of irreversible brain stem injury. Young et al. ${ }^{[27]}$ have defended that it would be necessary to control medical treatment closely via intracranial pressure (ICP) monitoring and to decide craniectomy later, when needed. DC varies according to the localization and the cause of increase in ICP. Decompression in diffuse brain injury shows variations as bilateral hemicraniectomy, bifrontal craniectomy, and circumferential craniectomy. Hatashita and Hoff ${ }^{[28]}$ have recommended craniectomy in case of occurrence of brain edema due to the changes in hydrostatic pressure gradient resulting in increased cerebral tissue tension and compliance. Ivamoto et al. ${ }^{[29]}$ have expressed that the survival of eighteen patients undergoing craniectomy for cerebral infarction was prolonged by $60 \%$; however, survival was further decreased and substantial disability developed in the patients who did not undergo craniectomy. Forsting et al. ${ }^{[30]}$ have demonstrated that DC did not only reduce mortality but also infarction size in cerebral ischemia. Kondziolka and Faz ${ }^{[31]}$ have carried out a study in five cases and stated that survival was prolonged with DC and long-term functional outcomes were encouraging. Engelhorn et al. ${ }^{[22]}$ have suggested that early reperfusion was the primary goal of the treatment of diffuse hemispheric ischemia and that early DC reduced infarction volume. However, they determined that DC together with reperfusion resulted in no difference in infraction and edema volume as compared to the single treatment regimen. Studies have revealed that early DC provides substantial improvement. In the present study, we also obtained similar results in the DC group. Only DC was performed in the above-mentioned studies, in the present study; however, medical treatment was also performed alone or in combination with DC. It was demonstrated that infarction volume was substantially decreased by DC combined with medical treatment. In their later study, Engelhorn et al. ${ }^{[23]}$ have compared the effectiveness of reperfusion, craniectomy 
or combination of these in malignant middle cerebral artery infarction. They have demonstrated that early reperfusion and craniectomy at I hour have similar efficacy but reperfusion after one hour is not beneficial; however, late craniectomy provides reduction in infarction volume even when it is performed at the $4^{\text {th }}$ or $12^{\text {th }}$ hour. They have also reported that combined treatment is also dependent on time and provides no additional efficacy unless performed within the first hour. In their previous study, Engelhorn et al. ${ }^{[22]}$ have found the infarction area to be $43.6 \%$ in the control group, $19.4 \%$ in the craniectomy group, $8.8 \%$ in the reperfusion group, and $18.7 \%$ in the reperfusion in combination with craniectomy group. In the present study, the mean infarction area was $27.9 \%$ in the control group and $10.5 \%$ in the craniectomy group. Although Engelhorn et al. ${ }^{[22]}$ reported the outcomes for the first 6 hours, 24-hour period of the present study demonstrated how effective the combination treatment was and that significance could be enhanced with further studies that would be carried out in longer periods.

In an experimental model of focal cerebral ischemia created by Doerfler et al. ${ }^{[24]}$ to study the combination of DC and hypothermia therapy, treatment at the $6^{\text {th }}$ and $24^{\text {th }}$ hours were discussed. A definite decrease in the infarction size was not determined only in the 6-hour hypothermia group; however, it was found that hypothermia performed together with DC was more beneficial in decreasing the ischemic infarction size. When the result of the study by Doerfler et al. ${ }^{[24]}$ was compared with that of the present study, it was $11.8 \%$ and $10.6 \%$, respectively, in the craniectomy groups. Moreover, as compared with the infarction ratio of $9.10 \%$ in the craniectomy+hypothermia group in the study by Doerfler et al., ${ }^{[24]}$ the present study determined a similar infarction ratio of $9.7 \%$ in the DC+MAN group. Hypertonic saline and mannitol infusions were administered in an experimental model of diffuse ischemic infarction by Toung et al..$^{[32]}$ and it was demonstrated that continuous infusion of hypertonic saline at the doses of $5 \%$ and $7.5 \%$ decreased infarction volume by increasing the amount of water in the brain and lungs. Reichenthal et al. ${ }^{[33]}$ have expressed that mannitol administered in the early period within the first 90 minutes provided a notable decrease in the amount of edema as compared to the late administration (based on density on computed tomography). In an experimental model of cerebral edema created by Albright et al. ${ }^{[34]}$ to evaluate systemic and intracranial effects of osmotic and oncotic therapies, five groups were constituted including crystalloid, mannitol, albumin, furosemide, and albu$\mathrm{min} /$ furosemide treatment groups. They observed decreased ICP in the treatment groups except for the albumin group. After the administration of high- or low-dose mannitol in an experimental model of ischemic stroke, Paczynski et al. ${ }^{[35]}$ observed that low-dose mannitol had more beneficial effects and led to decreased infarction volume. In the present study, we also preferred mannitol, intended to provide volume-reducing efficacy by decreasing ICP, and performed low-dose administration similar with the previous study. Sutherland et al. ${ }^{[36]}$ investigated the effects of indomethacin, nimodipine, and mannitol either alone or in combination in a rat model of cerebral ischemia and determined that combined use of many drugs provided the most beneficial effect in discontinuing ischemic process. Bhardwaj et al. ${ }^{[7]}$ have demonstrated that hypertonic saline treatment reduces brain edema that develop after stroke in rats undergoing reperfusion but worsenes infarction area due to an elevation in blood sodium concentration following $7.5 \%$ hypertonic saline infusion. Schwarz et al. ${ }^{[3]}$ have demonstrated that infarction volume-reducing efficacy of $7.5 \%$ and $6.5 \%$ saline infusion was higher than that of mannitol treatment. Ziai et al. ${ }^{[38]}$ have emphasized that clinical practice is available with hypertonic saline in infarction associated with ischemic stroke, tumor-related edema, intracranial hemorrhage, postoperative retraction edema, and traumatic brain injury; however, attention should be paid during treatment for likely hypernatremia. In the present study, better efficacy in terms of decrease in ischemic volume was observed with low-dose hypertonic saline as compared with mannitol; however, the difference was not statistically significant.

In conclusion, the present experimental study determined that both medical and surgical treatments significantly reduced infarction volume in irreversible ischemic injury (without reperfusion). When medical treatment groups were compared in terms of infarction volume-reducing efficacy, it was higher in the hypertonic saline group as compared with the mannitol group; however, the difference was not statistically significant. It was demonstrated that DC combined with medical treatment led to a higher reduction in the ischemic infarction volume. It was observed that DC together with hypertonic saline treatment significantly decreased the infarction volume at the highest. In the present experimental study, demonstration of substantial reduction in infarction volume with the use of DC combined with medical treatment in cerebral ischemia would shed light on clinical practices. It is necessary for neurologists and neurosurgeons dealing with ischemic events to discuss clinical therapeutic regimens, to conduct studies concerning whether reduction in edema and infarction volume after ischemia would make positive contribution or not to the clinical picture, and in addition, to consider surgical approach that might have favorable effect on ischemia-related complaints, which are likely to be overlooked.

\section{Conflict of interest: None declared.}

\section{REFERENCES}

1. Mukherjee D, Patil CG. Epidemiology and the global burden of stroke. World Neurosurg 2011;76(6 Suppl):85-90. CrossRef

2. Norrving B, Kissela B. The global burden of stroke and need for a continuum of care. Neurology 2013;80(3 Suppl 2):5-12. CrossRef

3. Truelsen T, Begg, S, Mathers C. Global burden of cerebrovascular disease. 2000. Retrieved from: http://www.who.int/healthinfo/statistics/ bod_cerebrovasculardiseasestroke.pdf. Last Access: 22 October 2014.

4. Raichle ME. The pathophysiology of brain ischemia. Ann Neurol 
1983;13:2-10. CrossRef

5. Ginsberg MD. Adventures in the pathophysiology of brain ischemia: penumbra, gene expression, neuroprotection: the 2002 Thomas Willis Lecture. Stroke 2003;34:214-23. CrossRef

6. Jivan K, Ranchod K, Modi G. Management of ischaemic stroke in the acute setting: review of the current status. Cardiovasc J Afr 2013;24:8692. CrossRef

7. Bhardwaj A, Ulatowski JA. Hypertonic saline solutions in brain injury. Curr Opin Crit Care 2004;10:126-31. CrossRef

8. Honeybul S, Ho KM. The current role of decompressive craniectomy in the management of neurological emergencies. Brain Inj 2013;27:97991. CrossRef

9. Rice JE 3rd, Vannucci RC, Brierley JB. The influence of immaturity on hypoxic-ischemic brain damage in the rat. Ann Neurol 1981;9:131-41.

10. Bederson JB, Pitts LH, Germano SM, Nishimura MC, Davis RL, Bartkowski HM. Evaluation of 2,3,5-triphenyltetrazolium chloride as a stain for detection and quantification of experimental cerebral infarction in rats. Stroke 1986;17:1304-8. CrossRef

11. Kawamura S, Li Y, Shirasawa M, Yasui N, Fukasawa H. Reversible middle cerebral artery occlusion in rats using an intraluminal thread technique. Surg Neurol 1994;41:368-73. CrossRef

12. LeBlanc MH, Li XQ, Huang M, Patel DM, Smith EE. AMPA antagonist LY293558 does not affect the severity of hypoxic-ischemic injury in newborn pigs. Stroke 1995;26:1908-15. CrossRef

13. Childs AM, Evans RH, Watkins JC. The pharmacological selectivity of three NMDA antagonists. Eur J Pharmacol 1988;145:81-6. CrossRef

14. Franke CL, Palm R, Dalby M, Schoonderwaldt HC, Hantson L, Eriksson B, et al. Flunarizine in stroke treatment (FIST): a double-blind, placebo-controlled trial in Scandinavia and the Netherlands. Acta Neurol Scand 1996;93:56-60. CrossRef

15. Cho S, Park EM, Febbraio M, Anrather J, Park L, Racchumi G, et al. The class B scavenger receptor CD36 mediates free radical production and tissue injury in cerebral ischemia. J Neurosci 2005;25:2504-12. CrossRef

16. Adibhatla RM, Hatcher JF, Dempsey RJ. Cytidine-5'-diphosphocholine affects CTP-phosphocholine cytidylyltransferase and lyso-phosphatidylcholine after transient brain ischemia. J Neurosci Res 2004;76:390-6.

17. Adibhatla RM, Hatcher JF, Dempsey RJ. Phospholipase A2, hydroxyl radicals, and lipid peroxidation in transient cerebral ischemia. Antioxid Redox Signal 2003;5:647-54. CrossRef

18. Adibhatla RM, Hatcher JF, Dempsey RJ. Citicoline: neuroprotective mechanisms in cerebral ischemia. J Neurochem 2002;80:12-23. CrossRef

19. Coimbra C, Drake M, Boris-Möller F, Wieloch T. Long-lasting neuroprotective effect of postischemic hypothermia and treatment with an anti-inflammatory/antipyretic drug. Evidence for chronic encephalopathic processes following ischemia. Stroke 1996;27:1578-85. CrossRef

20. Kollmar R, Schwab S. Ischaemic stroke: acute management, intensive care, and future perspectives. Br J Anaesth 2007;99:95-101. CrossRef

21. Tamura A, Graham DI, McCulloch J, Teasdale GM. Focal cerebral ischaemia in the rat: 1 . Description of technique and early neuropathological consequences following middle cerebral artery occlusion. J Cereb Blood Flow Metab 1981;1:53-60. CrossRef
22. Engelhorn T, Doerfler A, Kastrup A, Beaulieu C, de Crespigny A, Forsting $\mathrm{M}$, et al. Decompressive craniectomy, reperfusion, or a combination for early treatment of acute "malignant" cerebral hemispheric stroke in rats? Potential mechanisms studied by MRI. Stroke 1999;30:1456-63.

23. Engelhorn T, von Kummer R, Reith W, Forsting M, Doerfler A. What is effective in malignant middle cerebral artery infarction: reperfusion, craniectomy, or both? An experimental study in rats. Stroke 2002;33:61722. CrossRef

24. Doerfler A, Schwab S, Hoffmann TT, Engelhorn T, Forsting M. Combination of decompressive craniectomy and mild hypothermia ameliorates infarction volume after permanent focal ischemia in rats. Stroke 2001;32:2675-81. CrossRef

25. Delashaw JB, Broaddus WC, Kassell NF, Haley EC, Pendleton GA, Vollmer DG, et al. Treatment of right hemispheric cerebral infarction by hemicraniectomy. Stroke 1990;21:874-81. CrossRef

26. Rengachary SS, Batnitzky S, Morantz RA, Arjunan K, Jeffries B. Hemicraniectomy for acute massive cerebral infarction. Neurosurgery 1981;8:321-8. CrossRef

27. Young PH, Smith KR Jr, Dunn RC. Surgical decompression after cerebral hemispheric stroke: indications and patient selection. South Med J 1982;75:473-5. CrossRef

28. Hatashita S, Hoff JT. The effect of craniectomy on the biomechanics of normal brain. J Neurosurg 1987;67:573-8. CrossRef

29. Ivamoto HS, Numoto M, Donaghy RM. Surgical decompression for cerebral and cerebellar infarcts. Stroke 1974;5:365-70. CrossRef

30. Forsting M, Reith W, Schäbitz WR, Heiland S, von Kummer R, Hacke W, et al. Decompressive craniectomy for cerebral infarction. An experimental study in rats. Stroke 1995;26:259-64. CrossRef

31. Kondziolka D, Fazl M. Functional recovery after decompressive craniectomy for cerebral infarction. Neurosurgery 1988;23:143-7. CrossRef

32. Toung TJ, Chang Y, Lin J, Bhardwaj A. Increases in lung and brain water following experimental stroke: effect of mannitol and hypertonic saline. Crit Care Med 2005;33:203-60. CrossRef

33. Reichenthal E, Kaspi T, Cohen ML, Shevach I, Shalmon E, Bar-Ziv Y, et al. The ambivalent effects of early and late administration of mannitol in cold-induced brain oedema. Acta Neurochir Suppl (Wien) 1990;51:110-2. CrossRef

34. Albright AL, Latchaw RE, Robinson AG. Intracranial and systemic effects of osmotic and oncotic therapy in experimental cerebral edema. J Neurosurg 1984;60:481-9. CrossRef

35. Paczynski RP, Venkatesan R, Diringer MN, He YY, Hsu CY, Lin W. Effects of fluid management on edema volume and midline shift in a rat model of ischemic stroke. Stroke 2000;31:1702-8. CrossRef

36. Sutherland G, Lesiuk H, Bose R, Sima AA. Effect of mannitol, nimodipine, and indomethacin singly or in combination on cerebral ischemia in rats. Stroke 1988;19:571-8. CrossRef

37. Schwarz S, Schwab S, Bertram M, Aschoff A, Hacke W. Effects of hypertonic saline hydroxyethyl starch solution and mannitol in patients with increased intracranial pressure after stroke. Stroke 1998;29:1550-5. CrossRef

38. Ziai WC, Toung TJ, Bhardwaj A. Hypertonic saline: first-line therapy for cerebral edema? J Neurol Sci 2007;261:157-66. CrossRef 
DENEYSEL ÇALIŞMA - ÖZET

\title{
Dekompresif kraniektomi, hipertonik salin ve mannitol'ün deneysel serebral iskemi üzerine etkilerinin karşılaştırılması \\ Dr. Çağatay Çalıkoğlu, ${ }^{1}$ Dr. Mehmet Hüseyin Akgül, ${ }^{2}$ Dr. Osman Akgül, ${ }^{3}$ Dr. Ayşe Karataş ${ }^{4}$
}

\author{
${ }^{1}$ Atatürk Üniversitesi Tıp Fakültesi, Beyin ve Sinir Cerrahisi Anabilim Dalı, Erzurum \\ ${ }^{2}$ Seydişehir Devlet Hastanesi, Beyin ve Sinir Cerrahisi Kliniği, Konya \\ ${ }^{3}$ Düzce Devlet Hastanesi, Beyin ve Sinir Cerrahisi Kliniği, Düzce \\ ${ }^{4}$ Katip Çelebi Üniversitesi Tıp Fakültesi, Beyin ve Sinir Cerrahisi Kliniği, İzmir
}

AMAÇ: Serebral iskemi son derece önemli ve ciddi bir mortalite ve morbidite sebebidir. Serebral dokuyu iskemik zedelenmenin oluşturacağı hasardan korumak için seçilecek yöntem son derece önemlidir. Bu çalışmada kullanılan medikal ve cerrahi tedavi yöntemleri deneysel fare serebral iskemi modeli ile karşılaştırıldı, tek başına veya kombine uygulamalarında etki düzeyleri araştırıldı.

GEREÇ VE YÖNTEM: Erişkin erkek Sprague-Dawley sıçanlar $(n=30)$ altı gruba ayrıldı, sağ kommon karotis arter oklüzyonu ile serebral enfarkt oluşturuldu. Bir gruba iskemiden 12 saat sonra Dekompressif kraniectomi (DC) uygulandı. Diğer bir gruba ise iskemi sonrası I, I2 va 24 . saatlerde medikal tedavi verildi. Kontrol grubuna serum fizyolojik verilirken, bir gruba \%3 hipertonik saline, diğer bir gruba \%20 mannitol tedavisi. Sadece kraniyektom yapılanlar dekompressif kraniektomi grubu (DC), DC+HS grubu ise DC ve hipertonik salin verilenlerden oluştu. DC+MAN ise DC ve mannitol beraber verilen grubu olurturdu. Sıçanlar 24. saatin sonunda dekapite edildi, beyinleri alınarak patolojik olarak incelendi ve iskemi sahaları hesaplanarak tedaviye yanıtları değerlendirildi.

BULGULAR: Kontrol grubunda ortalama enfarkt alanı \%27.9, HS grubunda \% I3.7, MAN grubunda \% I5. I, DC grubunda \% I0.6, DC+HS grubunda \%8. I, ve DC\%+MAN \%9.7. Ortalama enfarkt alanları hemen tüm gruplarda kontrol grubuna gore düşük görüldü, HS ve MAN grupları arasında fark bulunamadı, DC grubunda bu iki gruba göre daha iyi sonuç elde edildi fakat en iyi sonuçlar DC+MAN grubunda tespit edildi.

TARTIŞMA: Serebral iskemik enfarkt tedavisinde hem medikal hem cerrahi etkili yöntemlerdir. Medikal tedavi yöntemleri arasında fark bulunamadı, halbuki cerrahi tedavi grubunda, medikal tedavi grubuna göre daha iyi sonuç elde edildi. Kombine tedavide diğerlerine göre en iyi sonuç alındı. Bu sonuçlar iskemik beyin zedelenmesinde en iy sonucun cerrahi ve medikal tedavi kombinasyonu olduğunu göstermektedir.

Anahtar sözcükler: Dekompresif kraniektomi; deneysel çalışma; hipertonik salin; mannitol; serebral iskemi.

Ulus Travma Acil Cerrahi Derg 2015;21(6):425-431 doi: 10.5505/tjtes.2015.45077 